\title{
QuikSCAT and SSM/I ocean surface winds for wind energy
}

\author{
Hasager, Charlotte Bay; Astrup, Poul; Nielsen, Per
}

Published in:

IEEE International Geoscience and Remote Sensing Symposium, 2007. IGARSS 2007.

Link to article, DOI:

10.1109/IGARSS.2007.4423602

Publication date:

2007

Document Version

Publisher's PDF, also known as Version of record

Link back to DTU Orbit

Citation (APA):

Hasager, C. B., Astrup, P., \& Nielsen, P. (2007). QuikSCAT and SSM/I ocean surface winds for wind energy. In IEEE International Geoscience and Remote Sensing Symposium, 2007. IGARSS 2007. (pp. 3507-3512). IEEE. https://doi.org/10.1109/IGARSS.2007.4423602

\section{General rights}

Copyright and moral rights for the publications made accessible in the public portal are retained by the authors and/or other copyright owners and it is a condition of accessing publications that users recognise and abide by the legal requirements associated with these rights.

- Users may download and print one copy of any publication from the public portal for the purpose of private study or research.

- You may not further distribute the material or use it for any profit-making activity or commercial gain

- You may freely distribute the URL identifying the publication in the public portal 


\section{QuikSCAT and SSM/I ocean surface winds for wind energy}

\author{
C.B. Hasager, P. Astrup \\ Wind Energy Department \\ Risoe National Laboratory - DTU \\ Roskilde, Denmark \\ charlotte.hasager@,risoe.dk, poul.astrup@risoe.dk
}

\author{
P. Nielsen \\ EMD International \\ Energi- og Miljødata International \\ Aalborg, Denmark \\ pn@emd.dk
}

\begin{abstract}
Ocean surface winds observed by satellite scatterometer (QuikSCAT) and passive microwave (SMM/I) provide valuable information for wind energy applications. In wind energy two long-term aspects on the offshore wind climate is of concern. One is the 20-year average necessary for the estimation of produced wind power during the life-time of a wind turbine (i.e. wind resource assessment); the other is the month-to-month variation in produced wind power (i.e. wind-indexing). In the present study, the offshore wind resource is estimated from QuikSCAT wind maps. The offshore wind climates at the North-European mid-latitudes and in the Atlantic trade belt zone are compared. Distinct differences are identified and these agree well with independent data from meteorological masts in the two regions. Seven years of twice daily observations from QuikSCAT are used for the offshore wind resource assessment. Wind-indexing is based on long-term trends observed in wind climate statistics. It is customary to observe winds and produced power in parallel in order to keep track of performance. Wind-indexing is based on long-term wind observations and the present study investigate variation in offshore and land-based variations during 18 years observed from SSM/I, other wind observations, model results and produced wind power. Very interestingly it is found that the offshore wind climate is different from wind climates over land in the North-European mid-latitudes.
\end{abstract}

Keywords - ocean wind, scatterometer, passive microwave, wind energy

\section{INTRODUCTION}

Ocean winds are interesting in the context of offshore wind energy resources and offshore wind farm power production. The potential of offshore winds for power production is large and plans for utilization of the resource are available in many countries. The first offshore wind farm was established in Denmark in the earlier 1990ties and since then another 9 offshore wind farms have been developed in Denmark. The total offshore capacity is $\sim 400 \mathrm{MW}$ in Denmark alone, and $\sim 700 \mathrm{MW}$ worldwide. The capacity is increasing fast www.ewea.org.

Long-term observations of in situ ocean winds are not available in general. The data collected are sparsely sampled and typically only for short periods. A wind farm project is planned with a 20-year life-time, i.e. the produced power during this period is essential for a wind farm project. In order to calculate the predicted offshore wind power production it is important to quantify variations in ocean winds during time and space. It is customary to observe winds accurately from a meteorological mast for at least one year (usually stored as 10 minute, 30-minute or hourly values) and then evaluate this observed 'wind-year' in the context of inter-annual variability. Years may be rich or poor in winds (similar to e.g. warm/cool or wet/dry years).

Ocean winds from satellite have been investigated from two sources, passive microwave data and scatterometer data. These are attractive data sources as both are readily available from data archives in the format of wind data. Passive microwave data provide ocean wind speed only whereas scatterometer provide ocean wind vectors. Both data sets are observed on a global scale as the instruments are installed on satellite platforms in polar sun-synchronic orbits.

\section{OCEAN WINDS FROM SATELLITE}

\section{A. Ocean wind speed from SSM/I}

Ocean winds have been observed from space for two decades with passive microwave radiometers. It is the Meteorological Program of the United States Department of Defense that is in charge of the Defense Meteorological Satellite Program (DMSP). Within DMSP a long series of Earth observing satellites have been active since the mid70 'ties. The series is called F-1 (from 1976), F-2 (from 1977), etc., up to currently operating satellite platforms F-13 (from 1995), F-14 (from 1997) and F-15 (from 1999, stopped in 2006). Since F-8 (from 1987) a passive microwave radiometer has been flown. This sensor is capable of measuring ocean wind speed (not direction). It is the Special Sensor Microwave Imager (SSM/I). Data from Remote Sensing Systems (RSS) at www.remss.com have been downloaded and analyzed [1]. Wind speed is stored in a $0.25^{\circ}$ by $0.25^{\circ}$ grid with up to 6 observations per day and valid at $10 \mathrm{~m}$ above sea level.

\section{B. Ocean wind vector from QuikSCAT}

The National Aeronautics and Space Administration (NASA) launched the NASA scatterometer (NSCAT) in 1996. Unfortunately NSCAT did not work for very long, only to 1997 and therefore, very quickly, the next scatterometer was launched. It is the SeaWinds instrument on-board the QuikSCAT satellite. It was launched in 1999. Observations are available since July 1999 from Remote Sensing Systems (RSS)

Danish Agency for Science Technology and Innovation, STVF/DSF, contract number 2058-03-0006 
at www.remss.com and wind vector data have been downloaded and analyzed [1]. Wind vectors are observed twice per day and stored as $0.25^{\circ}$ by $0.25^{\circ}$ grid and valid at $10 \mathrm{~m}$ above sea level.

\section{STUDY SiteS AND WINDS}

The Danish Seas is the main target of study as most of the installed offshore capacity is found here. The wind climate offshore varies with distance to shorelines and to the dimensions and roughness of the land-masses surrounding the seas. The North Sea is windier than the Baltic Sea in general. The wind climate in Denmark is dominated by mid-latitude frontal systems. The offshore mean wind speed in the Danish Seas is approximately similar to the mean wind speed at Cape Verde in the trade wind belt. Besides this, the wind climates are fairly different between the two sites as will be demonstrated in the analysis.

\section{A. Wind resource estimation}

The mean wind speed is indicative of the wind climate but far from sufficient when estimating the potential wind resource. A wind turbine operates in a range of wind speeds with a nonlinear response between wind speed and produced power. For low winds (e.g. below $4 \mathrm{~ms}^{-1}$ ) a turbine is not turning. For winds between e.g. 4 and $13 \mathrm{~ms}^{-1}$ more wind power is produced as winds increase; the potential power is proportional to the wind speed cubed. For winds in the range from 13 to 24 $\mathrm{ms}^{-1}$ a constant (full) rated power is produced and for winds beyond this limit, the wind turbine is stopped to avoid structural damage. The power production as a function of mean wind speed observed at the centre of the rotor (at hub-height) is called the power curve.

The variations in wind speed during time are significant at all time-scales ranging from seconds to minutes, hours, days, months, seasons, years and up to decades. A simple way to estimate the wind resource at a specific site is fitting the Weibull function (i.e. finding the shape, $\mathrm{k}$, and scale, A, parameters) to a histogram of wind speed variations during time. The power curve and Weibull paramaters can then readily be combined e.g. in WAsP (Wind Atlas and Analysis Program) [2] to provide the potential power production for a chosen wind turbine at a specific site.

The wind direction is important for the lay-out of a wind farm as one wind turbine upwind of another turbine will give shadowing effect (wake) downstream, hence the produced power from a turbine located in wake will be less as the mean speed wind is lower (and in addition the turbulence intensity is larger). Therefore wake effects are avoided as far as possible in offshore wind farms.

In the present study QuikSCAT ocean wind vectors observed twice daily during several years have been used to estimate the offshore wind climate in the North Sea, the Baltic Sea and near Cape Verde.

\section{B. Wind-indexing}

The wind-index is calculated at Energi- og Miljødata (EMD). Briefly described the monthly energy production from a number of wind turbine generators is compared to the same wind turbine generators' expected long-term average monthly production based on the longer production period.

Wind - index $=\frac{\text { Actual }- \text { monthly }- \text { production }}{\text { Long }- \text { term }- \text { monthly }- \text { production }}$

Reference http://www.vindstat.dk/PDF_sider/Windindex_DK_new_short.pdf.

The wind-index is used for giving information on the expected wind energy production in a given period compared to long-term estimates. This is important when planning new wind farms where local measurements typically only are available for a shorter period, as well as when checking the performance of existing wind farms.

As example the wind-index for January 2007 is shown in Fig. 1. It is seen that the wind power production was $124 \%$ larger than average for this month compared to long-term statistics. This is extraordinarily high. From Fig. 1 it may be noted that the wind-index varied between regions, from $197 \%$ in the northern part of to Denmark to $242 \%$ in the eastern part. At the site http://www.vindstat.dk/PDF sider/Vindindex aktuel.pdf it is possible to view the wind-index during the latest 12 months per region, the annual yearly variations for 5 years and the mean, maximum and minimum for 10 years [1].'

One of the challenges in wind-indexing is to identify accurate and reliable long-term wind data series for the analysis. This is to establish the long-term average. For the long-term level a wind-index shall be $100 \%$ by definition. However for defining the long-term period, there is no unique definition. Meteorological long-term periods normally are defined for 30 years but we have not yet a 30-year period with wind-index calculation. Traditional meteorological ground measurements are used. Also climate model results like NCEP/NCAR, available for each 6 hours. A processed version (MM5 Mesoscale model) is available named as World Wind

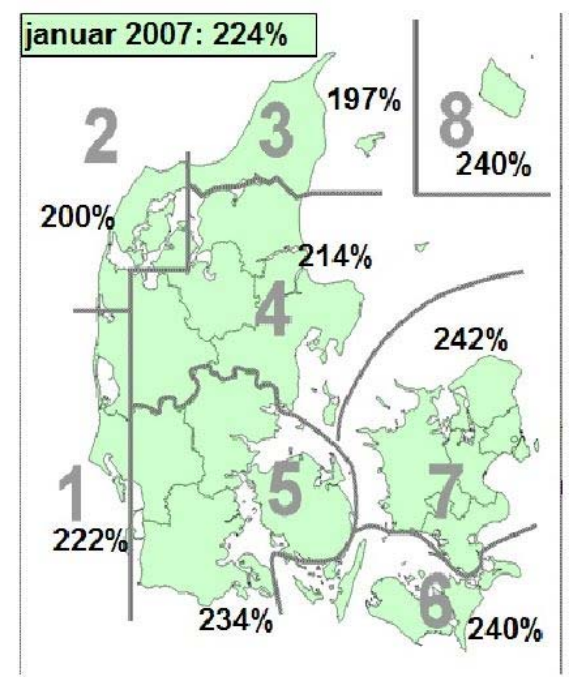

Figure 1. Wind-index for Denmark January 2007 from EMD http://www.vindstat.dk/. Courtesy: EMD. 
Atlas (WWA) is used. The climate model data has in general the problem that near surface wind phenomena are not represented. E.g. this means that for warmer regions with much temperature induced wind flow, the data becomes almost useless. Maybe newer models might compensate for this [1].

From satellites only SSM/I have a series of relevant length (19 years) and reasonably sampling per day (a few per day).

\section{RESULTS ON WIND CLIMATE FROM QUIKSCAT}

\section{A. Wind resource estimates}

Results based on QuikSCAT ocean wind vector data are from sites in the North Sea and Baltic Sea indicated in Fig. 2.

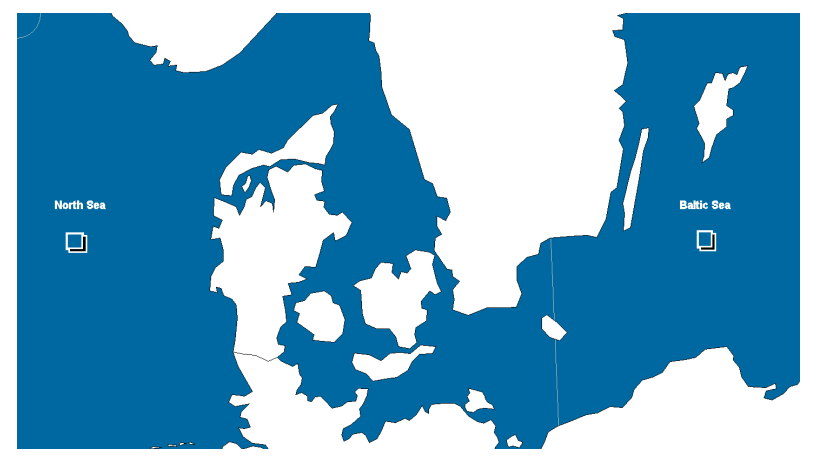

Figure 2. Position of two locations investigated.

The wind roses for the North Sea and the Baltic Sea in Fig. 3 shows that the winds in the North Sea are stronger than in the Baltic Sea and winds from all directions prevail at both sites. At both sites westerly flow is dominant.

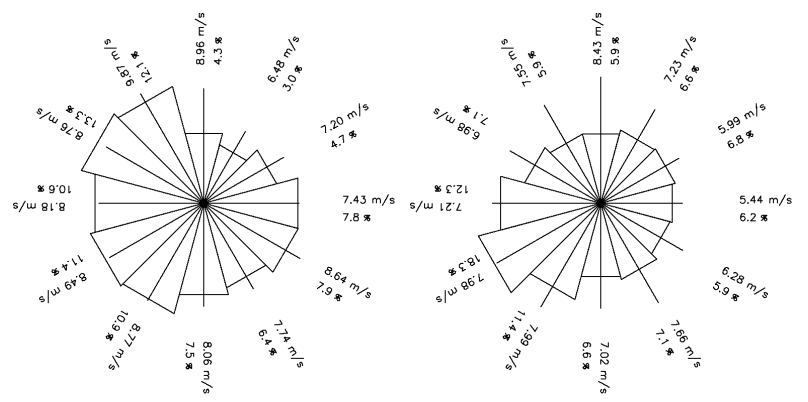

Figure 3. Wind roses observed from the central North Sea (left) and central Baltic Sea (right) from QuikSCAT in the period July 1999 to February 2007.

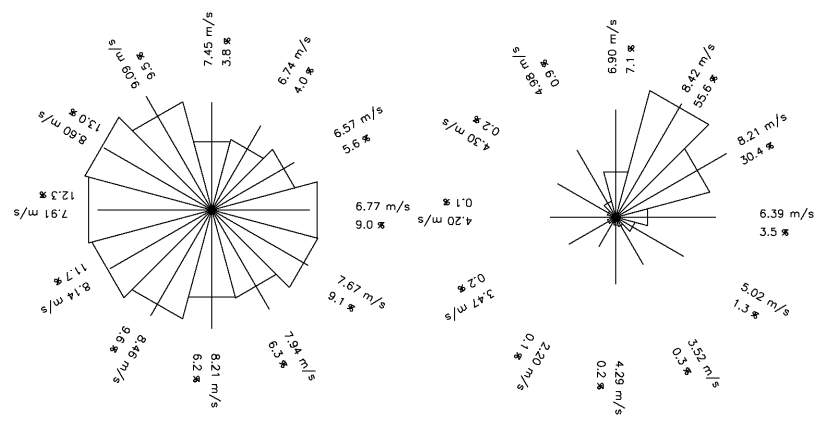

Figure 4. Wind rose near Horns Rev in the North Sea (left) and Santo Antão, Cape Verde (right) from QuikSCAT in the period July 1999 to Sep. 2006.
The wind rose near the island Santo Antão, Cape Verde is shown in Fig.4 based on QuikSCAT data. It is clear that trade winds from the northeast dominate at this site. Fig. 4 also shows the wind rose near Horns Rev in the North Sea [1]. This is a site near the coast where the largest offshore wind farm in the world is in operation.

It is interesting to compare the monthly variations in wind speed between Horns Rev in the North Sea and Cape Verde. The result is shown in Fig. 5. It is clear that the mean wind speed is around $8 \mathrm{~ms}^{-1}$ at both sites. The major difference is the much larger seasonal variability in wind speed in the North Sea than near Cape Verde. More results on winds in the North Sea and Cape Verde are available at

http://galathea3.emu.dk/satelliteeye/casestudies/capeverde/index uk.html.

The web-link is related to the educational material developed in the project Satellite Eye for Galathea 3 (www.satelliteeye.dk).
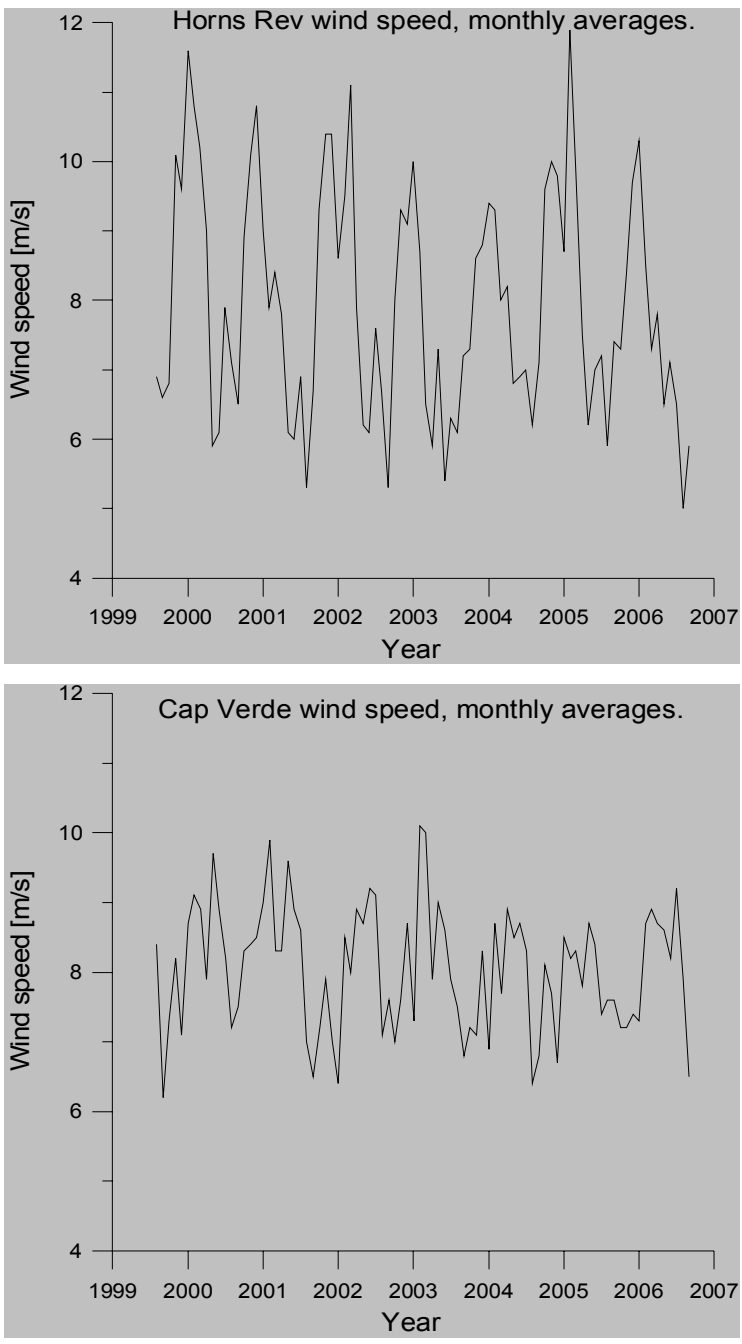

Figure 5. Monthly mean wind speed near Horns Rev in Denmark (8.0 longitude, 55.4 latitude) (above), and southwest of the island Santo Antão, Cape Verde (25.7 longitude, 16.8 latitude) (below) observed from QuikSCAT during seven years. From [1]. 
Comparison results between QuikSCAT wind direction and wind speed with offshore observations at the Horns Rev offshore wind farm were reported [3]. The comparison results were fairly good with slope near 1 and bias of $3^{\circ}$ for wind direction and slope near 0.96 and bias of $0.3 \mathrm{~ms}^{-1}$ for the hourly mean wind speed from the linear regression results. More scatter was found in the comparison with 10-minute means than for 1-hour means. It was interpreted as follows: the satellite captures a snap-shot wind map in seconds and the spatial scale of the observations is $25 \mathrm{~km}$. This spatial scale apparently corresponds better to hourly observations.

The offshore meteorological observations from the offshore mast located near the offshore wind farm were kindly provided by DONG energy.

\section{RESULTS ON WIND CLIMATE FROM SSM/I}

\section{A. Wind-index results}

$\mathrm{SSM} / \mathrm{I}$ wind speed data were used in the analysis on windindex. First, however, is presented the monthly wind speed variations observed by SSM/I during 10 years at the locations in the North Sea and the Baltic Sea indicated in Fig. 2. The result is shown in Fig. 6. In all months, except August, the mean wind speed was higher in the North Sea than in the Baltic Sea

For wind index calculation it is important that the number of observations is large and that the data are accessible in nearreal-time (NRT) or within a couple of days. For passive microwave $(\mathrm{SSM} / \mathrm{I})$ there is a NRT product at the web. The NRT SSM/I wind maps are recalculated in the following weeks and the fully processed SSM/I wind maps are uploaded about 3 weeks after recording [1].

A test was made in the SAT-WIND project on the differences between the NRT SSM/I and the final product. The differences were small, e.g. changes were found near sea ice margins and near hurricane centers and squall lines (heavy tropical rain). In other words, the changes found have to do with the sea ice margin and precipitation flags. Both things are

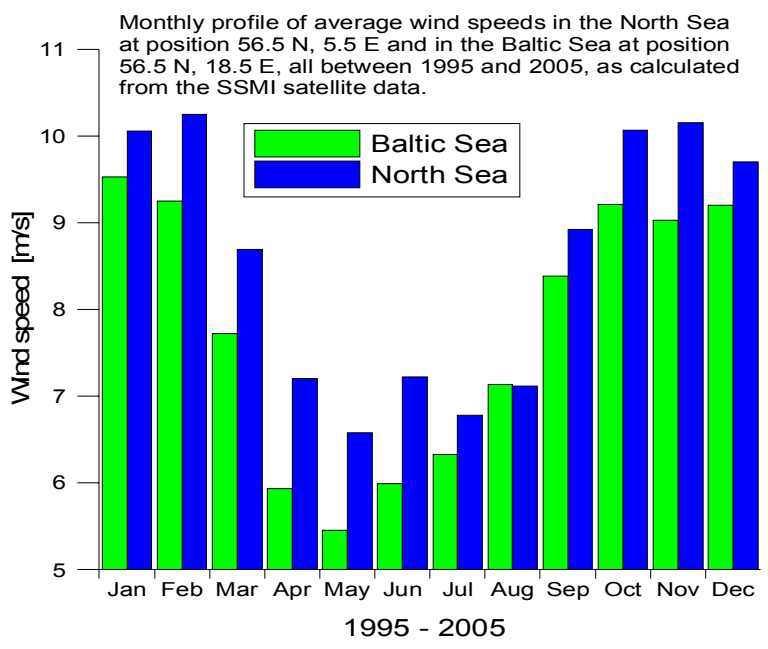

Figure 6. SSM/I wind speed data monthly averages from 10 years from an area in the North Sea and an area in the Baltic Sea. From [4]. typically found outside the Danish area. Hence it will be possible to rely on the NRT product for wind-index calculation in the Danish Seas. The wind climate was calculated from the fully processed wind maps [1].

The SSM/I Pathfinder data products include the daily geophysical data and time-averaged data as follows in table I.

The wind-index experiment with SSM/I wind speed data was made for two sites, one in the North Sea and one in the Baltic Sea (see Fig. 2). For each of these two sites observations from four grid cells were extracted. Fig. 7 presents the number of valid wind observations in the entire dataset [1].

From the wind speeds of the 4 neighboring grid cells, the average was taken because then most possible records were obtained, even if only one of the 4 points was available. For each of the mean wind speeds a wind index was calculated based on simply squared wind speed with a "power curve limiter" at $15 \mathrm{~ms}^{-1}$, meaning that at wind speeds above $15 \mathrm{~ms}^{-1}$ the wind index simply was set to $15^{2}$.

The resulting long-term average wind speeds based on all approved SSM/I data for the 18 year of data analyzed, the mean wind speeds were $7.7 \mathrm{~ms}^{-1}$ for the Baltic Sea and $8.3 \mathrm{~ms}^{-1}$ for the North Sea.

Calculation of the wind-index includes the following. To get an offshore wind farm relevant wind-index, the SSM/I wind speed data were extrapolated to $80 \mathrm{~m}$ above sea level with an assumed logarithmic profile and a shear of 0.1 . This gave a scaling factor of 1.23. The result is presented in Fig. 8 for the North Sea and the Baltic Sea. In this graph also the EMDver.06 wind-index is included [1].

TABLE I. AVAILABLE AVERAGED WIND PRODUCTS FROM SSM/I.

\begin{tabular}{|c|c|}
\hline daily & $\begin{array}{c}\text { orbital data mapped to 0.25 degree grid, data overwritten } \\
\text { by later data }\end{array}$ \\
\hline 3-day & average of 3 days ending on file date \\
\hline weekly & average of 7 days ending on the Saturday file date \\
\hline monthly & average of all data within month \\
\hline
\end{tabular}

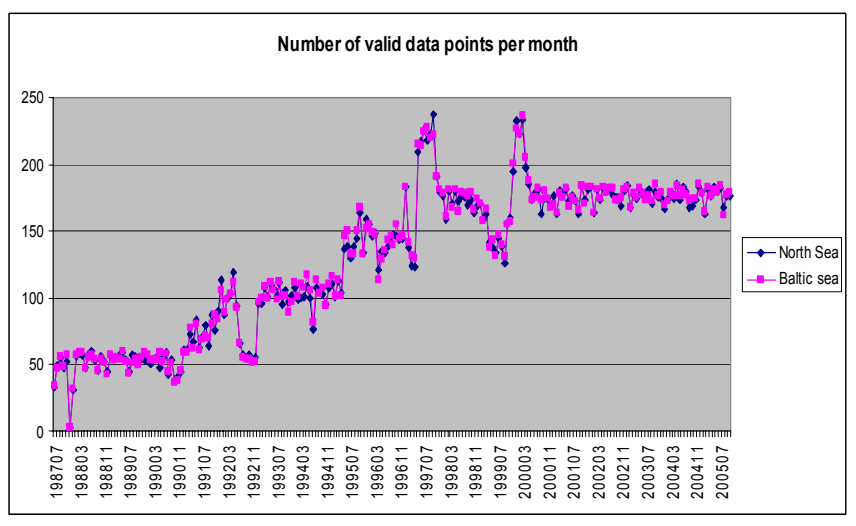

Figure 7. From 1987-1990 typically 2 data points per day increases to 6 data points per day from around year 2000 - in-between some changes we do not know the reasons for, but probably the periods with many data are based on more satellites operating in parallel. From [1]. 
The very first observation from Fig. 8 was that the decreasing trend in the EMD-ver.06 onshore wind turbine generators (WTG)-based index was NOT seen in the offshore indexes.

The second observation was that there were correlations regarding low and high winds during the years. Especially from 1998-2005 there was a good correlation. This is important because in this period the onshore WTG-index had a very high accuracy (i.e. it was based on many relative large turbines). At the same time there were many SSM/I observations (6 data points per day) thus a relatively high level of quality. Before 1998 the data sources were of poorer quality for the WTGindex. Also there were less SSM/I data points per day.

The very interesting issue for both present and future offshore projects is if this really tells us that the offshore wind energy variations are much less than we have seen onshore. It would then mean that the future energy production expectation must be considered as around $100 \%$ based on last 5 years, whereas the onshore expectations are $7 \%$ below average.

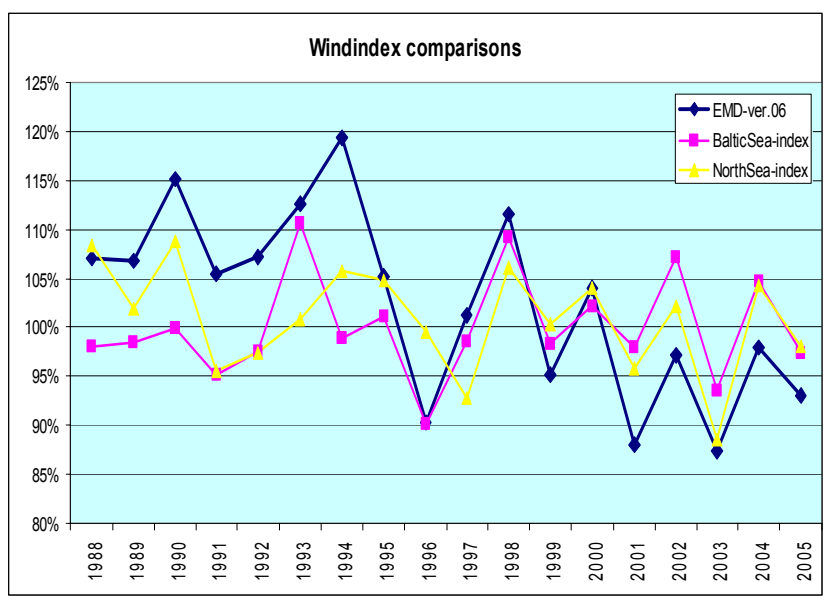

Figure 8. Comparison of EMD-ver.06 Danish WTG-based index with SSM/I wind-indexes from the Baltic Sea and the North Sea. From [1].

\section{DISCUSSION}

Satellite-based ocean wind observations are interesting in offshore wind engineering as this technology partly depends on long-term statistics on ocean winds. The satellite ocean wind observations cover the entire globe and data are available from several years, around 7 years from QuikSCAT and around 19 years from SSM/I. Many other instruments observe ocean winds, see [1] for a review.

QuikSCAT has the advantage of wind vector observation compared to SSM/I that observes only wind speed. Another advantage of QuikSCAT is that wind maps cover regions closer to the coastline than SSM/I. So far offshore wind farms are located only in coastal regions but this may change in the future. The wind maps of QuikSCAT do not cover the nearcoastal regions where the offshore wind farms are located. Only Synthetic Aperture Radar (SAR) offers direct mapping of winds near and within the present offshore wind farms, e.g. [5, $6,7,8]$. SAR observes a location only a few times per month.
QuikSCAT wind observations can be used to calculate wind resource statistics. These are useful in pre-feasibility studies on offshore wind resources. The satellite-based results are not adequate for siting of wind farms. In this case the financial decisions are made and very accurate observations are needed. It is foreseen that decisions on where to place a meteorological offshore mast could be based in part on the offshore wind statistics based on QuikSCAT (or SAR).

SSM/I wind observations seem most appropriate in windindexing as only wind speed is observed. The advantage is the frequent sampling rate (6 per day) during several years. Furthermore the accessibility to near-real-time (NRT) wind products of an apparently high quality means that the data potentially could be used operationally in wind-indexing.

\section{CONCLUSION}

Ocean wind mapping based on satellite technologies, passive microwave and scatterometer, have been investigated in regard to offshore wind farming. QuikSCAT wind vector data calculated to wind roses and as monthly variations compare well to general knowledge of wind statistics in contrasting regions (the North Sea, the Baltic Sea, Cape Verde). In a former study QuikSCAT winds were found to compare well to offshore meteorological mast observations near the largest offshore wind farm in the world, the Horns Rev wind farm in the North Sea.

An interesting finding from the SSM/I wind data analysis comparing observations from the North Sea and the Baltic Sea to the Danish wind-index from EMD (Energi- og Miljødata) shows the ocean wind statistics based on SSM/I have less variation during time. In other words, the potential offshore wind resource may be more attractive than generally assumed.

\section{ACKNOWLEDGMENT}

We are thankful to the institutes that allow free access to satellite-based ocean wind maps based on QuikSCAT and SSM/I satellite observations from PODAAC and Remote Sensing Systems (RSS). Offshore meteorological data provided by DONG energy are acknowledged.

\section{REFERENCES}

[1] Hasager, C. B., Astrup, P., Nielsen, M., Christiansen, M. B., Badger, J., Nielsen, P., Sørensen, P. B., Barthelmie, R. J., Pryor, S. C. \& Bergström, H. SAT-WIND Final report. Risø-R-1586(EN), 1-131. 2007. Roskilde, Denmark, http://www.risoe.dk/rispubl/VEA/ris-r-1586.htm

[2] Mortensen, N., Heathfield, D. N., Landberg, L., Rathmann, O., TROEN, I. \& Petersen, E. L. Wind Atlas Analysis and Wind Atlas Analysis and Application program:WAsP 7.0 Help Facility. ISBN 87-550-2667-2, 1277. 2000. Roskilde, Risø National Laboratory

[3] Hasager, C. B., Barthelmie, R. J., Christiansen, M. B., Nielsen, M. \& Pryor, S. C. (2006). Quantifying offshore wind resources from satellite wind maps: study area the North Sea. Wind Energy, 9, 63-74

[4] Hasager, C. B., Astrup, P., Christiansen, M. B., Nielsen, M. \& Barthelmie, R. J. Wind resources and wind farm wake effects offshore observed from satellite. 1-10. 2006. Proceedings of the European Wind Energy Conference and Exhibition (EWEC) 2006, Athens, Greece.

[5] Christiansen, M. B., Koch, W., Horstmann, J. \& Hasager, C. B. (2006). Wind resource assessment from C-band SAR. Remote Sensing of Environment, 105, 68-81. 
[6] Christiansen, M. B. \& Hasager, C. B. (2005). Wake effects of large offshore wind farms identified from satellite SAR. Remote Sensing of Environment, 98, 251-268

[7] Christiansen, M. B. \& Hasager, C. B. (2006). Using airborne and satellite SAR for wake mapping offshore. Wind Energy, 9, 437-455

[8] Monaldo, F., Kerbaol, V., Clemente-Colón, P., Furevik, B., Horstmann, J., Johannessen, J., Li, X., Pichel, W., Sikora, T. D., Thomson, D. J. \& Wackerman, C. The SAR measurement of ocean surface winds:an overview. ESA SP-565, 15-32. 2003. ESA. Proceedings of the Second Workshop Coastal and Marine Applications of SAR, 2-12 September 2003, Svalbard, Norway. 